\title{
The Need of Public Administration An Islamic Perspective for Higher Education in Indonesia
}

\author{
Wisber Wiryanto \\ Center of Administrative Reform Studies \\ National Institute of Public Administration \\ Jakarta, Indonesia \\ wisberwiryanto@yahoo.com
}

\begin{abstract}
Public Administration is a branch of Social Science disciplines taught at universities in Indonesia. Indonesia is a country that is predominantly Muslim. However, the education system faces problems of secularization that is split between education and religion. This can be seen in the teaching of public administration disciplines which mostly uses Western worldview than the Islamic worldview. The results of the study, to several libraries of the universities in Indonesia showed that the administration public textbooks available to students mostly from the Western textbooks than Islamic textbooks, that it has generated a lot of administrative problems in Indonesia; while the textbooks approach puts Islamic worldview and religion as a source of knowledge, to achieve happiness in the world and life hereafter inwardly and outwardly very little available. Therefore, Islamic public administration is needed; and it requires steps for Islamization of public administration in higher education in Indonesia; to empowering character education for national defence.
\end{abstract}

Keywords: Islamic public administration; Islamic worldview; western worldview; secularization.

\section{INTRODUCTION}

The problem faced by Muslims in the field of education today is secularism in the various branches of science disciplines. Discipline contemporary science is taught in college until now, is a contemporary Western secular discipline. The use of Western secular sciences emptying the science of revelation has caused the problem. In other word, the education system faces problems of secularization that is split between education and religion.

The secular sciences using the Western worldview that does not match the environmental conditions of the religious community. Indonesia is a country that is predominantly Muslim. Indonesia contains statistical data adherents of Islam in Indonesia in 2010 reached $207,176,162$ people or 87.18 percent [1].

Higher education in Indonesia should be developed using Islamic worldview that provide safety of life in this world and the hereafter; not use Western secular worldview that brings destruction. Therefore, it takes effort to develop knowledge of contemporary Islamic perspective for higher education in Indonesia, through the Islamization of knowledge.

One of the social sciences are more influenced by secular Western theory is the science of the public administration. This can be seen in the teaching of public administration disciplines mostly uses Western worldview than the Islamic worldview. The result has been confusion, abuse of authority, corruption, tragedy and destruction, as is often reported in the media.
As a solution is needed nonwestern public administration, that is public administration an Islamic perspective or islamization of public administration. This study formulates problems as following "Is there a need for public administration an Islamic perspective in Indonesia?". This study aims to meet the needs of public administration an Islamic perspective for Higher Education in Indonesia. Therefore, it is necessary to conduct a study entitled "The Need of Public Administration an Islamic Perspective for Higher Education in Indonesia".

\section{RESEARCH METHOD}

Appraisal method used is library research method. Collecting and analizyng data used descriptive qualitative, through textbook and an online library that are relevant for this study. The focus of study: the needs of public administration disciplines in Islamic perspective. The locus of study: some institutions of higher education in Indonesia that have faculties/ departments science of public administration, among others: (1) University of Indonesia (UI); (2) State Islamic University Sultan Syarif Kasim (UIN Suska); (3) State University of Yogyakarta (UNY); and (5) Universitas Terbuka (UT). This research was conducted in 20162017.

\section{RESULT AND DISCUSSION}

Result collecting data in the locus of study: some institutions of higher education in Indonesia that have faculties/ departments science of public administration, through an online library of each university, to know the number of public administration textbooks in both western-secular and Islamic perspectives (see Table I).

\section{TABLE I.}

THE COMPARISON OF THE WESTERN AND ISLAMIC PUBLIC ADMINISTRATION TEXTBOOKS AT SOME UNIVERSITIES IN INDONESIA

\begin{tabular}{lll}
\hline \multirow{2}{*}{ Institution of the University } & \multicolumn{2}{c}{$\begin{array}{l}\text { Administration Public } \\
\text { textbooks }\end{array}$} \\
\cline { 2 - 3 } & Western & Islamic \\
\hline 1. University of Indonesia (UI) & 102 & 6 \\
2. State Islamic University Sultan Syarif & 48 & 3 \\
$\quad$ Kasim (UIN Suska) & & \\
3. State University of Yogyakarta (UNY) & 46 & 1 \\
4. Universitas Terbuka (UT) & 38 & 1 \\
\hline
\end{tabular}

Source: Online library of each university related, accessed on September 19, 2016.

The facts of secular education hegemony show the secularization of the Public Administration existing science at

Corresponding author: Wisber Wiryanto 
various universities. The result of searching on-line four libraries in Indonesian universities, an inequality shows the Western and Islamic existence of Public Administration textbook as follows: (1) an online library of the University of Indonesia = 102: 6 [16]; (2) an online library of the State Islamic University Syarif Kasim Sultan Riau = 48: 3 [17]; (3) an online library of the State University of Yogyakarta = 46: 1 [18]; (4) The UT Online Library $=38: 1$ [19] (see table v). Thus, the university library in Indonesia is very likely to provide many Western public administration than the Islamic Public Administration textbooks.

TABLE II.

List of the title Islamic Public Administration Textbook at some UNIVERSITIES IN INDONESIA

\begin{tabular}{|c|c|c|c|c|}
\hline Title of Textbook & UI & $\begin{array}{l}\text { UIN } \\
\text { Suska }\end{array}$ & UNY & UT \\
\hline $\begin{array}{l}\text { 1. Al Buraey, Muhammad, Islam Platform } \\
\text { for Alternative Development } \\
\text { Administration (Islam Landasan } \\
\text { Alternatif Administrasi Pembangunan), } \\
\text { (Ttranslate) Budiman, Achmad Nashir, } \\
\text { Jakarta: Rajawali, } 1996 .\end{array}$ & $\sqrt{ }$ & $\sqrt{ }$ & - & - \\
\hline $\begin{array}{l}\text { 2. Noer, Deliar, Administration of Islam in } \\
\text { Indonesia, Ithaca-Newyork: Cornel } \\
\text { University, } 1978 .\end{array}$ & $\sqrt{ }$ & - & - & - \\
\hline $\begin{array}{l}\text { 3. Noer, Deliar, Administration of Islam in } \\
\text { Indonesia (Administrasi Islam di } \\
\text { Indonesia), Jakarta: Rajawali, } 1983 .\end{array}$ & $\sqrt{ }$ & $\sqrt{ }$ & - & - \\
\hline $\begin{array}{l}\text { 4. Rahim, Husni, Systems Administration } \\
\text { Authorities Islam: The Sultanate of } \\
\text { Palembang (Sistem Otoritas } \\
\text { Administrasi Islam: Masa Kesultanan di } \\
\text { Palembang), Jakarta: Logos Wacana } \\
\text { Ilmu, 1998. }\end{array}$ & $\sqrt{ }$ & $\sqrt{ }$ & - & - \\
\hline $\begin{array}{l}\text { 5. Sherwani, Haroon Khan, Learning } \\
\text { opinion of Islamic scholars on State } \\
\text { Administration (Mempelajari pendapat } \\
\text { sarjana Islam tentang Administrasi } \\
\text { Negara), Jakarta: Tintamas, } 1964 .\end{array}$ & - & - & $\sqrt{ }$ & - \\
\hline $\begin{array}{l}\text { 6. Sholeh, Abdul Rahman Sholeh, dan } \\
\text { Muhtadi, Siddik, piety towards God } \\
\text { Almighty as the basis for Orderly } \\
\text { Development Administration (Takwa } \\
\text { terhadap Tuhan Yang Maha Esa sebagai } \\
\text { dasar Pembinaan Tertib Administrasi), } \\
\text { Jakarta: Gunung Agung, } 1982 \text {. }\end{array}$ & - & - & - & $\sqrt{ }$ \\
\hline
\end{tabular}

Source: an online library of each university related, accessed on September 19, 2016.

Data collection shows the university library, public administration perspective of western secular textbooks more than the Islamic perspective of public administration. List of titles public administration in the perspective of Islam; found served more as follows. The university library collections above; while the more is the public administration in the textbook- secular western perspective. Moreover, the books of public administration in other Islamic perspective can be found in other places, such as at the University of Ibn Khaldun Bogor. List of public administration textbook titles in Islamic perspective; found in this study, can be presented as above.

Based on these data it is known that public administration textbooks in Islamic perspective there are as many as 6 titles of books (see Table II). This shows that the number of public administration textbook titles Islamic perspective is small when compared with the number of titles in the perspective of public administration textbook western / secular are more numerous (see table I). Therefore, the university concerned should make efforts to increase the number of titles public administration textbook in the perspective of Islam, through the collection and writing other books so that the collection of books to be increased to meet the needs of the development of the science of public administration in the perspective of Islam in college Indonesia.

The results of the above-mentioned lessons learned in meeting the needs of the science of public administration in the perspective of Islamic universities in Indonesia, to be exploited and further developed; and their examples of curriculum/silaby science of public administration in the perspective of Islam in college in the state of Bangladesh and Thailand; this research tries to arrange an alternative curriculum/ syllabus in Islamic perspective in order to meet the needs of the science of public administration in the Islamic perspective for universities in Indonesia (see Table III).

TABLE III.

DRAFT Syllabus/CURRICULUM Public AdMINISTRATION IN THE PERSPECTIVE OF ISLAM FOR UNIVERSITIES IN INDONESIA

\begin{tabular}{lll}
\hline Courses & $\begin{array}{l}\text { Subject / } \\
\text { Material }\end{array}$ \\
& \\
\hline $\begin{array}{l}\text { 1. Administrati } \\
\text { on }\end{array}$ & $\begin{array}{l}\text { Islamic } \\
\text { Administra } \\
\text { tion }\end{array}$ & $\begin{array}{l}\text { Hude, M. Darwis, et.al, Horizon Science in } \\
\text { the Qur'an (Cakrawala Ilmu dalam al- } \\
\end{array}$ \\
& $\begin{array}{l}\text { Qur'an), Jakarta: Pustaka Firdaus, 2002. } \\
\text { Chapter: Administration. }\end{array}$
\end{tabular}

Muhammad, Qutb Ibrahim, How Prophet Manages Economy, Finance and Administrative System (Bagaimana Rasulullah Mengelola Ekonomi, Keuangan dan Sistem Administrasi), Jakarta: GP-Press, 2007.

Noer, Deliar, Administration of Islam in Indonesia, Ithaca-Newyork: Cornell University, 1978.

Noer, Deliar, Administration of Islam in Indonesia (Administrasi Islam di Indonesia), Jakarta: Rajawali, 1983.

Rahim, Husni, System Administration Authorities Islam: The Sulatanate of Palembang, (Sistem Otoritas Administrasi Islam: Masa Kesultanan di Palembang), Jakarta: Logos Wacana Ilmu, 1998

Sholeh, Abdul Rahman, and Muhtadi, Siddik, Piety towards God Almighty as the basis for Orderly Development Administration, 
(Takwa terhadap Tuhan Yang Maha Esa sebagai dasar Pembinaan Tertib Administrasi), Jakarta: Gunung Agung, 1982.

\begin{tabular}{lll}
\hline 2.Development & Islamic & Al Buraey, Muhammad, Islam Platform for \\
Administration & Developmen1 & Alternative Development Administration \\
& Administrati & Islam (Landasan Alternatif Administrasi \\
& on & Pembangunan), Translate: Budiman, Nasir, \\
& & A, Jakarta: Rajawali, 1996.
\end{tabular}

\begin{tabular}{|c|c|c|}
\hline 3. Management & $\begin{array}{l}\text { Islamic } \\
\text { Administrati } \\
\text { on: } \\
\text { Controlling }\end{array}$ & $\begin{array}{l}\text { Ahmad, Khaliq, et.al (Ed.), Issues in Islamic } \\
\text { Management, Selangor: IIUM Press, } 2011 . \\
\text { Chapter: Institu-tion of Administrative } \\
\text { Control. }\end{array}$ \\
\hline & $\begin{array}{l}\text { Islamic } \\
\text { Administra } \\
\text { tion: } \\
\text { Accountab } \\
\text { ility }\end{array}$ & $\begin{array}{l}\text { Mahmood, Riaz, The Concept of } \\
\text { Administrative Accountability in Islam, } \\
\text { Lahore-Pakistan: Maqbool Academy, } 2001 \text {. }\end{array}$ \\
\hline $\begin{array}{l}\text { 4. Public } \\
\text { Administrati } \\
\text { on }\end{array}$ & $\begin{array}{l}\text { Islamic } \\
\text { Public } \\
\text { Administra } \\
\text { tion }\end{array}$ & $\begin{array}{l}\text { Ahmad, Khaliq, et.al (Ed.), Issues in Islamic } \\
\text { Management, Selangor: IIUM Press, } 2011 . \\
\text { Chapters: Managerial Ethic of Public } \\
\text { Administrators from the Qur'anic } \\
\text { Perspective. }\end{array}$ \\
\hline
\end{tabular}

Tahrir, Hizbut, Khilafah State Structure of government and administration (Struktur Negara Khilafah pemerintahan dan administrasi), Ttranslate: A.R., Yahya, Jakarta: HTI-Press, 2006.

Yasid, The Islamic Perspective of changes in government administration and law, JIIS 6 : $1,2012$.

Draft curriculum / syllabus in the perspective of Islam are expected to be tested for in the educational process in the college, to meet the needs of the science of public administration in the perspective of Islamic universities in Indonesia. Various criticisms and feedback from the pilot implementation of the curriculum / syllabus was used to refine the draft curriculum / syllabus so that it can meet the needs of the public administration disciplines in Islamic perspective, as expected.

\section{IV.CONCLUSION}

Islamic Public Administration is needed; and it requires steps for Islamization of Public Administration in higher education in Indonesia; to empowering character education for national defense. The development needs of science Islamic public administration can be done in various ways, among others, by (1) the study of the Qur'an as a source of knowledge; (2) the implementation of the Islamization of knowledge; (3) the preparation of the curriculum/syllabus of the public administration; and (4) writing the public administration textbook in the Islamic perspective on higher education in Indonesia.

\section{ACKNOWLEDGMENT}

Praise to the presence of God, the author would like to thank those who have provided assistance in conducting a study whose results outlined in this article. The parties who have helped, among others: (1) The leadership and employees of the state administration reform study centers Institute of Public Administration who has an appreciation for this study; (2) In the family, both parents, and the wife and children of writers who have provided support in conducting this study; (3) In lecturers and friends at the University of Ibn Khaldun Bogor who have given to the author for sharing knowledge; and (4) the other parties which cannot be mentioned one by one, including the library staff who have provided the support necessary data.

\section{REFERENCES}

[1] A. Naim and H. Syaputra. Citizenship of the Tribe, Religion and Language Everyday Indonesian Population: Results of the 2010 Population Census ( Kewarganegaraan Suku Bangsa, Agama dan Bahasa Sehari-hari Penduduk Indonesia: Hasil Sensus Penduduk 2010), Jakarta: Badan Pusat Statistik, 2011 , p. 10.

[2] A. Rahman, Quranic Science, Al-Qur'an Source of Science (Al-Qur'an Sumber Ilmu Pengetahuan), Arifin, M., Jakarta: PT Rineka Cipta, 2000, pp. 46-353.

[3] M.D. Hude, H. Basri, M. Abbas and M.A. Al-Hafizh, The horizon of Science in the Qur'an (Cakrawala Ilmu dalam al-Quran), Jakarta: Penerbit Pustaka Firdaus, Bale Kajian Tafsir al-Qur'an Pase and Institut Perguruan Tinggi Ilmu al-Qur'an, 2002, p.20.

[4] I.R. Al-Faruqi, Islamization of Knowledge: General Principles and Workplan, Brentwood, Maryland, International Institute of Islamic Thought, 1982: pp. 54-57.

[5] Wiryanto, W., The Islamization of Human Resource Management Textbook for Higher Education in Indonesia Through al-Faruqi's Theory, 2016, pp. 89., in press.

[6] List of semester courses in Faculty of Social and Political Sciences, Islamic University of Kalimantan, Banjarmasin, http://fisip.uniska-bjm.ac.id/ uploads/file/file/matakuliah_an_ganjil. pdf., accessed on Oktober 3, 2016.

[7] W.M.N.W. Daud, Islamization of Contemporary Sciences and the Role of Islamic University (Islamisasi Ilmu-Ilmu Kontemporer dan Peran Universitas Islam)s, Universitas Ibn Khaldun Bogor \& Centre for Advanced Studies on Islam, Science and Civilisation Universiti Teknologi Malaysia, 2013 , cet. 1, p. 34 .

[8] Langputeh, S., The Experience of Thai Muslim Community: A Case of Yala Islamic http://www.iais.org.my/e/attach/2nd_ICIHE/ppts/Dr.\%20sukree\%20 langputeh $\% 20$ The $\% 20$ Experience $\% 20$ of $\% 20$ Thai $\% 20$ Muslim $\% 20$ Commu nity.pdf, accessed on September 1, 2016.

[9] University of Dhaka, Islamization of Curriculum Project Public Administration, http://i-epistemology.net/v1/economics-a-business/214islamization-of-curriculum-project-public-administration.html, accessed on September 20, 2016.

[10] Universitas Islam Sunan Gunung Djati Bandung, Distribution of Courses Each Semester of the State Administration Department (Distribusi Mata Kuliah Tiap Semester Jurusan Administrasi Negara), http://asepwildanfirdaus.blogspot.co.id/2015/10/distribusi-mata-kuliahtiap-semester.html, accessed on September 20, 2016.

[11] Universitas Islam Negeri Sultan Syarif Kasim, Jurusan Administrasi Negara - $\quad$ https://uin-suska.ac.id/fakultas/fakultas-ekonomi-dan-ilmusosial/jurusan-administrasi-negara/, accessed on September 10, 2016.

[12] Noer, D., Administration of Islam in Indonesia, Ithaca, New York: Cornel University, 1978, pp. 8-65.

[13] Noer, D., Administration of Islam in Indonesia (Administrasi Islam di Indonesia), Jakarta: Rajawali, 1983.

[14] Rahim, H., System of Islamic Administration Authority: The Sultanate Period in Palembang (Sistem Otoritas Administrasi Islam: Masa Kesultanan di Palembang), Jakarta: Logos Wacana Ilmu, 1998.

[15] Ali, M.D., Azhari, T, and Daud, H, Islam for Political and Legal Discipline: Book of Islamic Religious Education at Public Higher Education (Islam 
untuk Disiplin Ilmu Hukum dan Sosial Politik: Buku Daras Pendidikan Agama Islam pada Perguruan Tinggi Umum), Jakarta: Bulan Bintang, 1988 , pp. v, 1-128.

[16] Universitas Indonesia Library, http://lib.ui.ac.id, accessed on September 19, 2016.

[17] Universitas Islam Negeri Sultan Syarif Kasim Riau, http:/lib.uinsuska.ac.id, accessd on September 19, 2016;

[18] Universitas Negeri Yogyakarta, http:/library.uny.ac.id, accessed on September 19, 2016.

[19] Universitas Terbuka Library, http://www.pustaka.ut.ac.id/pac/opac/, accessed on September 19, 2016. 